\title{
SPK PEMILIHAN MEDIA ONLINE SEBAGAI SARANA PROMOSI MENGGUNAKAN METODE AHP
}

\author{
Risqy Siwi Pradini ${ }^{1}$, Indra Dharma Wijaya² \\ Program Studi Teknik Informatika, Jurusan Teknologi Informasi, Politeknik Negeri Malang \\ ${ }^{1}$ risqysiwipradini@gmail.com, ${ }^{2}$ indra.dharma@gmail.com
}

\begin{abstract}
Abstrak
Usaha Mikro, Kecil, dan Menengah atau UMKM adalah perusahaan kecil yang dimiliki dan dikelola oleh seseorang atau dimiliki oleh sekelompok kecil orang dengan jumlah kekayaan dan pendapatan tertentu. Contoh UMKM adalah Cornnies dan Indri Collection. Produksi Cornnies dan Indri Collection ini masih dengan skala kecil, karena kurang dikenal oleh masyarakat luas, oleh karena itu dibutuhkan suatu promosi. Salah satu media promosi adalah memanfaatkan media online sebagai sarana promosi. Akan tetapi media internet memiliki banyak jenis, oleh karena itu dibutuhkan pengkajian dan pengukuran untuk masing-masing jenisnya. Untuk mengukur masing-masing jenis media online, dibutuhkan suatu metode AHP (Analytic Hierarchy Process). Sistem ini dapat menjadi pendamping pengambilan keputusan mengenai pemilihan media online sebagai sarana periklanan. Dengan adanya aplikasi ini, pengambilan keputusan menjadi lebih efektif, serta menghasilkan keputusan yang terbaik bagi pihak Cornnies dan Indri Collection. Keputusan ini telah diuji dengan membandingkan hasil output sistem dengan hasil keputusan manual.
\end{abstract}

Kata kunci : sistem pendukung keputusan, promosi, media online, AHP

\section{Pendahuluan}

Usaha Mikro, Kecil, dan Menengah atau UMKM telah mampu membuktikan eksistensinya dalam perekonomian di Indonesia. Undang-undang yang mengatur tentang UMKM adalah UndangUndang Nomor 20 Tahun 2008. Dalam undangundang tersebut dijelaskan bahwa sebuah perusahaan yang digolongkan sebagai UMKM adalah perusahaan kecil yang dimiliki dan dikelola oleh seseorang atau dimiliki oleh sekelompok kecil orang dengan jumlah kekayaan dan pendapatan tertentu.

Contoh dari UMKM adalah Cornnies dan Indri Collection. Cornnies merupakan produk brownies jagung yang diproduksi oleh wirausaha mandiri yang berada di Trenggalek. Produksi Cornnies masih dengan skala kecil, karena kurang dikenal oleh masyarakat luas, oleh karena dibutuhkan suatu promosi. Sedangkan Indri Collection adalah wirausaha di bidang konveksi yang berada di Kota Malang.

Salah satu media promosi adalah memanfaatkan media online sebagai sarana promosi, mengingat internet merupakan pusat informasi saat ini. Menurut data dari Asosiasi Penyelenggara Jasa Internet Indonesia (APJII), pengguna internet di Indonesia pada tahun 2014 mencapai 107 juta orang perhari, bahkan diproyeksikan pada tahun 2015 pengguna internet di Indonesia mencapai 139 juta orang perhari, dan akan meningkat terus dari tahun ke tahun berikutnya. Media online dapat dinikmati oleh semua khalangan. Hampir setiap hari masyarakat mengakses internet khususnya media online seperti social media, email, search engine dan lain sebagainya. Maka dari itu media online sebagai sarana promosi sangat berpeluang dan cocok untuk menyebarkan informasi mengenai produk Cornnies dan Indri Collection yang dapat menarik konsumen untuk melakukan pembelian produk Cornnies dan Indri Collection.

Media internet memiliki banyak jenis, oleh karena itu dibutuhkan pengkajian dan pengukuran untuk masing-masing jenisnya. Untuk mengukur masing-masing jenis media online, dibutuhkan suatu metode AHP (Analytic Hierarchy Process). Metode AHP yang dirumuskan dalam penelitian ini diawali dengan penstrukturan permasalahan ke dalam bentuk hierarki yang dilanjutkan dengan pemberian bobot pada masing-masing kriteria jenis media online dan pada akhirnya akan melakukan perangkingan. Sehingga akan ditemukan peringkat jenis media online yang berpotensi untuk melakukan promosi pada produk Cornnies dan Indri Collection

Tujuan penelitian ini adalah untuk membantu memberikan rekomendasi jenis media online sebagai sarana promosi yang dapat mengenalkan dan menarik minat beli masyarakat akan produk Cornnies dan Indri Collection dalam bentuk sistem terkomputerisasi yang menerapkan metode AHP.

\section{Tinjauan Pustaka}

\subsection{Sistem Pendukung Keputusan}


Menurut Santoso (2012), definisi sistem pendukung keputusan adalah sistem berbasis komputer yang interaktif yang membantu pengambil keputusan memanfaatkan data dan model untuk menyelesaikan masalah-masalah yang terstruktur. Sistem pendukung keputusan ditujukan untuk keputusan yang tidak dapat didukung oleh algoritma.

\subsection{Pemasaran Online}

Pemasaran online berada di dalam sub isi promosi, di mana dalam mempromosikan suatu produk atau jasa, produsen mengawali kegiatannya dengan membangun berbagai saluran informasi, dan persuasi untuk menjual, serta memperkenalkan suatu gagasan dari suatu produk yang ingin dipasarkan. Menurut Kartika (2014), berikut merupakan beberapa jenis / macam online marketing:

1. Email marketing dan sales letter

2. Partnership Marketing

3. Search Engine Marketing

4. Social Media Marketing

Terdapat kriteria-kriteria yang dapat dijadikan acuan untuk menghitung AHP pada promosi online. Adapun 4 kriteria yang diterapkan antara lain:

1. Biaya pemasangan iklan

2. Target pasar

3. Waktu promosi

4. Brand imange

Untuk menentukan prioritas antar kriteria, maka masing-masing kriteria harus diberi pembobotan. Di dalam dunia marketing/pemasaran, para marketer tidak terlalu memikirkan biaya. Sehingga biaya memiliki bobot paling rendah diantara kriteria yang lain. Sedangkan kriteria target pemasaran memiliki bobot yang lebih daripada waktu promosi, karena target pasar lebih memiliki dampak dikenalnya iklan tersebut daripada waktu promosi. Dan waktu promosi memiliki bobot yang lebih tinggi daripada brand image karena untuk mendapatkan citra atau pengakuan dari konsumen diperlukan waktu yang lama. Dan target pasar bobotnya sebanding dengan brand image karena jika suatu iklan sudah memenuhi target pasar yang ditentukan maka dengan segera produk tersebut akan mendapat brand image / citra produk.

\subsection{AHP}

Prinsip kerja AHP adalah penyederhanaan suatu persoalan kompleks yang tidak terstruktur, menjadi bagian-bagiannya serta menata dalam suatu hirarki. Menurut Kusrini (2007), langkah-langkah analisa menggunakan metode AHP:

a. Mendefinisikan masalah dan menentukan solusi yang diinginkan, lalu menyusun hirarki dari permasalahan yang dihadapi. Penyusunan hirarki adalah dengan menetapkan tujuan yang merupakan sasaran sistem secara keseluruhan pada level teratas.

b. Perhitungan bobot kriteria untuk memeriksa konsistensi. Jika nilainya lebih dari $10 \%$, maka penilaian data judgement harus diperbaiki. Namun jika rasio konsistensi (CI/IR) kurang atau sama dengan 0,1, maka hasil perhitungan bisa dinyatakan benar.

c. Melakukan perangkingan alternatif dengan cara mengalikan bobot alternatif dan bobot kriteria. Hasil dengan nilai paling besar dinyatakan mendapatkan rekomendasi pertama.

\section{Pembahasan}

Dalam penelitian ini menggunakan metode AHP untuk mendapatkan rekomendasi jenis media online yang paling sesuai untuk menempatkan promosi. Berikut ini adalah langkah-langkah pembahasan analisa menggunakan metode AHP:

a. Menyusun Hierarki

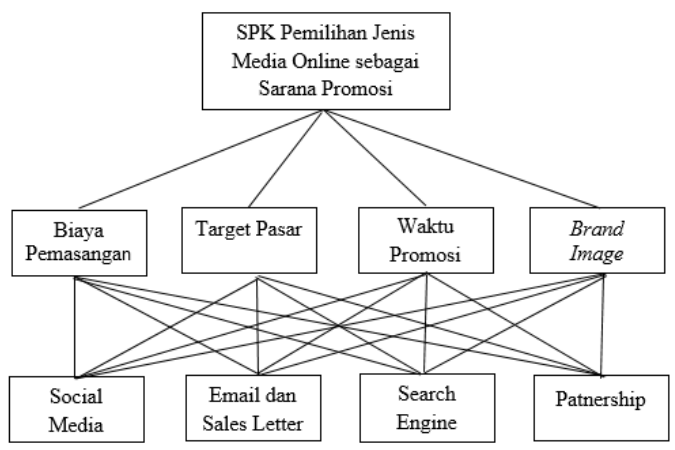

Gambar 1 Hierarki Masalah

b. Perhitungan Bobot Kriteria

Untuk perhitungan ini menggunakan bentuk matrik berpasangan dengan menggunakan skala penilaian 1 sampai 9.

Tabel 1 Matriks Perbandingan Berpasangan

\begin{tabular}{|l|c|c|c|c|}
\hline KRITERIA & Biaya & $\begin{array}{c}\text { Target } \\
\text { Pasar }\end{array}$ & $\begin{array}{c}\text { Waktu } \\
\text { Promosi }\end{array}$ & $\begin{array}{c}\text { Brand } \\
\text { Image }\end{array}$ \\
\hline Biaya & 1 & $1 / 3$ & $1 / 3$ & $1 / 3$ \\
\hline Target Pasar & 3 & 1 & 2 & 1 \\
\hline $\begin{array}{l}\text { Waktu } \\
\text { Promosi }\end{array}$ & 3 & $1 / 2$ & 1 & 2 \\
\hline Brand Image & 3 & 1 & $1 / 2$ & 1 \\
\hline
\end{tabular}

Tabel 2 Normalisasi dan AVG

\begin{tabular}{|l|l|l|l|l|l|}
\hline & Biaya & $\begin{array}{l}\text { Target } \\
\text { Pasar }\end{array}$ & $\begin{array}{l}\text { Waktu } \\
\text { Promosi }\end{array}$ & $\begin{array}{l}\text { Brand } \\
\text { Image }\end{array}$ & AVG \\
\hline Biaya & 0,1 & 0,188 & 0,087 & 0,077 & 0,095 \\
\hline $\begin{array}{l}\text { Target } \\
\text { Pasar }\end{array}$ & 0,3 & 0,353 & 0,522 & 0,231 & 0,351 \\
\hline $\begin{array}{l}\text { Waktu } \\
\text { Promosi }\end{array}$ & 0,3 & 0,177 & 0,261 & 0,462 & 0,299 \\
\hline $\begin{array}{l}\text { Brand } \\
\text { Image }\end{array}$ & 0,3 & 0,353 & 0,130 & 0,231 & 0,254 \\
\hline
\end{tabular}


Selanjutnya melakukan normalisasi dan menghitung rata-rata tiap baris dengan cara menjumlahkan nilai kriteria tiap barisnya lalu dibagi jumlah kriteria.

Lalu menghitung weight sum vector dengan cara mengkalikan AVG dengan data pada tabel 1 yang telah diubah menjadi nilai desimal.

$$
\begin{gathered}
{\left[\begin{array}{c}
(0,095)(1)+(0,351)(0,333)+(0,299)(0,333)+(0,254)(0,333) \\
(0,095)(3)+(0,351)(1)+(0,299)(2)+(0,254)(1) \\
(0,095)(3)+(0,351)(0.5)+(0,299)(1)+(0,254)(2) \\
(0,095)(3)+(0,351)(1)+(0,299)(0,5)+(0,254)(1)
\end{array}\right]} \\
=\left[\begin{array}{l}
0,397 \\
1,490 \\
1,269 \\
1,041
\end{array}\right]
\end{gathered}
$$

Selanjutnya adalah menghitung consistency vector dengan cara melakukan pembagian pada weight sum vector dengan AVG.

$$
\left[\begin{array}{l}
0,397 / 0,095 \\
1,490 / 0,351 \\
1,269 / 0,299 \\
1,041 / 0,254
\end{array}\right]=\left[\begin{array}{l}
4,161 \\
4.241 \\
4.232 \\
4.105
\end{array}\right]
$$

Menghitung consistency index (CI). Langkah pertama menghitung nilai $\lambda$ dengan rumus:

$$
\begin{aligned}
& \lambda=\frac{C V_{1}+C V_{2}+\ldots C V_{n}}{n} \\
& \lambda=\frac{4,161+4,241+4,232+4.105}{4}=4,185 \\
& C I=\frac{\lambda-n}{n-1} \\
& C I=\frac{4,185-4}{4-1}=0,062
\end{aligned}
$$

Langkah selanjutnya adalah menghitung consistency ratio. Untuk menentuan konsistensi dapat menggunakan rumus:

$$
C R=\frac{C I}{R I}
$$

Untuk nilai CI telah diketahui, akan tetapi RI belum diketahui. RI adalah random consistency index dimana $\mathrm{n}$ merupakan jumlah kriteria yang ada. Karena $\mathrm{n}=4$ maka RI nya adalah $=0.9$ maka $C R=$ $\frac{0,062}{0,9}=0.0684$ (Nilai Konsisten).

c. Perhitungan Bobot Alternatif

Selanjutnya melakukan perhitungan pada masing-masing alternatif. Nilai matriks perbandingan alternatif yang diterapkan adalah seperti tabel-tabel di bawah ini.

Tabel 3 Matriks Kriteria Biaya Pemasangan

\begin{tabular}{|c|c|c|c|c|}
\hline $\begin{array}{c}\text { BIAYA } \\
\text { PEMASANGAN }\end{array}$ & A1 & A2 & A3 & A4 \\
\hline A1 & 1 & 2 & 3 & 0,5 \\
\hline A2 & 0,5 & 1 & 3 & 0,5 \\
\hline A3 & 0,333 & 0,333 & 1 & 0,333 \\
\hline A4 & 2 & 2 & 3 & 1 \\
\hline
\end{tabular}

Tabel 4 Matriks Kriteria Target Pasar

\begin{tabular}{|c|c|c|c|c|}
\hline $\begin{array}{c}\text { TARGET } \\
\text { PASAR }\end{array}$ & A1 & A2 & A3 & A4 \\
\hline A1 & 1 & 3 & 2 & 2 \\
\hline A2 & 0,333 & 1 & 0,333 & 0,333 \\
\hline A3 & 0,5 & 3 & 1 & 0,5 \\
\hline A4 & 0,5 & 3 & 2 & 1 \\
\hline
\end{tabular}

Tabel 5 Matriks Kriteria Waktu Promosi

\begin{tabular}{|c|c|c|c|c|}
\hline $\begin{array}{c}\text { WAKTU } \\
\text { PROMOSI }\end{array}$ & A1 & A2 & A3 & A4 \\
\hline A1 & 1 & 3 & 2 & 2 \\
\hline A2 & 0,333 & 1 & 0,333 & 0,333 \\
\hline A3 & 0,5 & 3 & 1 & 0,5 \\
\hline A4 & 0,5 & 3 & 2 & 1 \\
\hline
\end{tabular}

Tabel 6 Matriks Kriteria Brand Image

\begin{tabular}{|c|c|c|c|c|}
\hline $\begin{array}{c}\text { BRAND } \\
\text { IMAGE }\end{array}$ & $\mathrm{A} 1$ & $\mathrm{~A} 2$ & $\mathrm{~A} 3$ & $\mathrm{~A} 4$ \\
\hline $\mathrm{A} 1$ & 1 & 3 & 2 & 2 \\
\hline $\mathrm{A} 2$ & 0,333 & 1 & 0,333 & 0,333 \\
\hline $\mathrm{A} 3$ & 0,5 & 3 & 1 & 0,5 \\
\hline $\mathrm{A} 4$ & 0,5 & 3 & 2 & 1 \\
\hline
\end{tabular}

Selanjutnya data pada tabel-tabel di atas diolah menjadi normalisasi dan dihitung AVGnya. Nilai AVG yang didapat nantinya akan dijadikan bobot alternatif tersebut.

Tabel 7 AVG Tiap Kriteria Cornnies

\begin{tabular}{|l|c|c|c|c|}
\hline & $\begin{array}{c}\text { Biaya } \\
\text { Pemasangan }\end{array}$ & $\begin{array}{c}\text { Target } \\
\text { Pasar }\end{array}$ & $\begin{array}{c}\text { Waktu } \\
\text { Promosi }\end{array}$ & $\begin{array}{c}\text { Brand } \\
\text { Image }\end{array}$ \\
\hline A1 & 0,286 & 0,406 & 0,406 & 0,406 \\
\hline A2 & 0,208 & 0,098 & 0,098 & 0,098 \\
\hline A3 & 0,098 & 0,208 & 0,208 & 0,208 \\
\hline$\underline{\text { A4 }}$ & $\underline{0,406}$ & $\underline{0,288}$ & $\underline{0,288}$ & $\underline{0,288}$ \\
\hline
\end{tabular}

Pada tabel 8 adalah nilai akhir yang diperoleh dari perkalian antara tabel 7 dengan AVG kriteria yang telah dihitung sebelumnya pada point 2 .

Tabel 8 Nilai Akhir

\begin{tabular}{|c|c|}
\hline Alternatif & Nilai \\
\hline A1 & 0,395 \\
\hline A2 & 0,109 \\
\hline A3 & 0,198 \\
\hline A4 & 0,299 \\
\hline
\end{tabular}

Dari perhitungan di atas rekomendasi pertama yaitu A1 karena nilainya paling tinggi daripada nilai altrnatif yang lainnya.

\section{Implementasi}

Hasil implementasi SPK pemilihan jenis media online sebagai sarana promosi pada bagian input matriks banding berpasangan untuk kriteria dapat dilihat pada gambar 2 . 


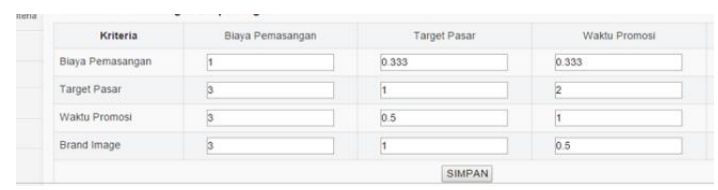

Gambar 2 Matriks Input Kriteria

Setelah inputan di atas diisi maka sistem akan mulai menghitung inputan dengan menggunakan rumus-rumus AHP yang telah ditetapkan. Dan sistem dapat menampilkan detail perhitungan AHP.

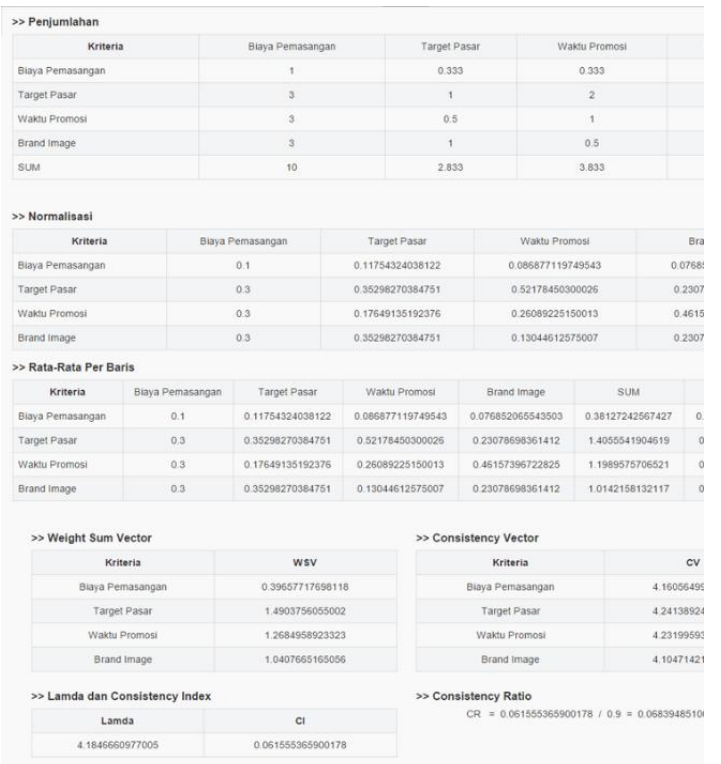

Gambar 3 Detail AHP Kriteria

Selain menampilkan detail perhitungan, sistem ini juga dapat menampilkan data yang diinputkan pada matriks konsisten/tidak konsisten. Nilai dinyatakan konsisten apabila nilai yang didapatkan $\leq 0,1$. Dan nilai dinyatakan tidak konsisten jika nilai yang didapatkan $>0,1$. Jika nilai kriteria tidak konsisten maka diharuskan melakukan perhitungan kembali.

Penilaian dinyatakan NILAI KONSISTEN karena hasilnya adalah $\underline{0.068394851}$ Gambar 4 Kesimpulan Konsistensi

Selanjutnya melakukan perbandingan pada masing-masing alternatif.

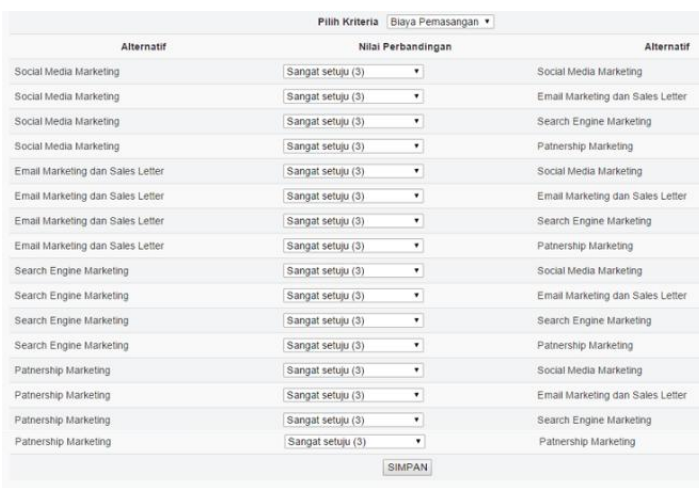

Gambar 5 Inputan Perbandingan Alternatif

Maka akan ditemukan hasil rekomendasinya dalam bentuk data dan grafik.

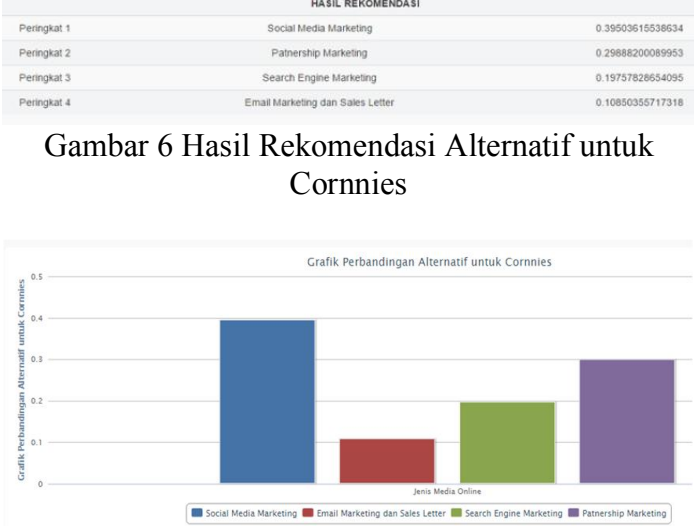

Gambar 7 Grafik Rekomendasi Alternatif untuk Cornnies

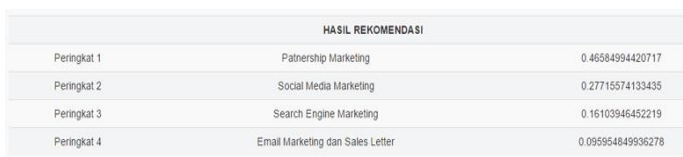

Gambar 8 Hasil Rekomendasi Alternatif untuk Indri Collection

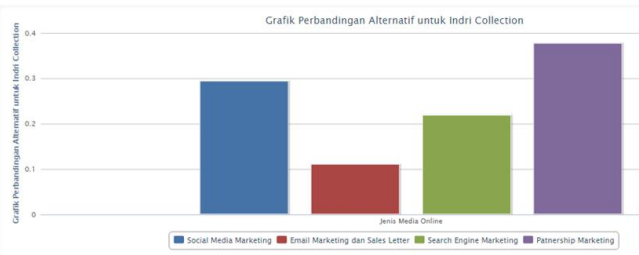

Gambar 9 Grafik Rekomendasi Alternatif untuk Indri Collection

\section{Kesimpulan dan Saran}

\subsection{Kesimpulan}

Dari penelitian ini dapat diperoleh beberapa kesimpulan sebagai berikut:

1. Sistem ini telah berhasil menerapkan metode AHP untuk pengambilan keputusan pemilihan jenis 
media online sebagai sarana promosi dengan studi kasus Cornnies dan Indri Collection.

2. Hasil pengujian menunjukkan bahwa perancangan sistem telah menghasilkan sistem yang dapat membantu mendapatkan rekomendasi pemilihan jeinis media online sebagai sarana promosi secara otomatis. Hasil pengujian menunjukkan bahwa sistem bersifat dinamis.

3. Hasil pengujian menunjukkan bahwa performasi sistem ini sudah cukup baik dan menghasilkan hasil yang akurat. Hasil pengujian menunjukkan perbandingan antara analisa AHP manual menggunakan Excel dengan Sistem ini hasilnya akurat dengan tingkat kecocokan 100\%.

\subsection{Saran}

Saran yang diberikan untuk pengembangan penelitian ini adalah:

1. Sistem dibuat agar lebih userfriendly sehingga pengguna tidak kesusahan dalam menjalankan sistem ini.

2. Belum adanya fasilitas laporan yang dapat mendukung sistem ini.
3. Sistem pendukung keputusan dalam penelitian ini masih dibuat dengan sederhana dan bisa dikembangka menjadi lebih baik.

\section{Daftar Pustaka:}

Haas, R. \& Meixner, O. An Illustrated Guide To The Analytic Hierarchy Process. Vienna: University of Natural Resources and Applied Life Sciences.

Kartika, Trecya. 2014. Pengaruh Kualitas Produk, Kepercayaan Konsumen Dan Pengetahuan Tentang Media Sosial Internet Terhadap Minat Beli Konsumen Online. Bengkulu: Universitas Bengkulu.

Kusrini, M. Kom. 2007. Konsep dan Aplikasi Sistem Pendukung Keputusan. Yogyakarta: Penerbit ANDI.

Santoso, Nurudin. 2012. Modul Ajar Sistem Pendukung Keputusan. Malang: Politeknik Negeri Malang.

Utaminingsih, Dwi. 2014. Sistem Pendukung Keputusan Untuk Menempatkan Iklan Produk pada Program Televisi Menggunakan AHP. Jurnal Ilmiah Universitas Dian Nuswantoro Semarang. 